\title{
Molecular mechanism of the schedule-dependent synergistic interaction in EGFR-mutant non-small cell lung cancer cell lines treated with paclitaxel and gefitinib
}

Hua Cheng ${ }^{1,2}$, She-Juan An', Song Dong', Yi-Fang Zhang ${ }^{1}, X^{1}$-Chao Zhang ${ }^{1}$, Zhi-Hong Chen', Jian-Su', Yi-Long $\mathrm{Wu}^{1 *}$

\begin{abstract}
Background: Chemotherapy combined concurrently with TKls produced a negative interaction and failed to improve survival when compared with chemotherapy or TKls alone in the treatment of non-small cell lung cancer (NSCLC). The present study investigated the sequence-dependent interaction between paclitaxel and gefitinib and clarified the underlying mechanism.

Methods: The effects on cell proliferation, EGFR signaling pathway, and TGF $\alpha$ expression were evaluated in a panel of human NSCLC cell lines harboring EGFR mutations with three different combination sequences: sequential treatment with paclitaxel followed by gefitinib $(T \rightarrow G)$, sequential treatment with gefitinib followed by paclitaxel $(G \rightarrow T)$, or concomitant treatment $(T+G)$.

Results: The sequence-dependent anti-proliferative effects differed between EGFR-TKI-sensitive and -resistant cell lines carrying EGFR mutations. A synergistic anti-proliferative activity was obtained with paclitaxel treatment followed by gefitinib in all cell lines, with mean Cl values of 0.63 in Hcc827, 0.54 in PC-9, 0.81 in PC-9/GR, and 0.77 in $\mathrm{H} 1650$ cells for the $T \rightarrow G$ sequence. The mean $\mathrm{Cl}$ values for the $\mathrm{G} \rightarrow T$ sequence were 1.29 in Hcc827, 1.16 in PC9, 1.52 in $P C-9 / G R$, and 1.5 in $\mathrm{H} 1650$ cells. The mean $\mathrm{Cl}$ values for $\mathrm{T}+\mathrm{G}$ concomitant treatment were 0.88 in Hcc827, 0.91 in PC-9, 1.05 in PC-9/GR, and 1.18 in H1650 cells. Paclitaxel produced a dose-dependent increase in EGFR phosphorylation. Paclitaxel significantly increased EGFR phosphorylation compared with that in untreated controls (mean differences: $+50 \%$ in Hcc827, $+56 \%$ in PC-9, $+39 \%$ in PC-9/GR, and $+69 \%$ in H1650 cells; $p<0.05$ ). The $\mathrm{T} \rightarrow \mathrm{G}$ sequence produced significantly greater inhibition of EGFR phosphorylation compared with the opposite sequence (mean differences: -58\% in Hcc827, -38\% in PC-9, -35\% in PC-9/GR, and -30\% in H1650 cells; $p<0.05$ ). Addition of a neutralizing anti-TGF $\alpha$ antibody abolished paclitaxel-induced activation of the EGFR pathway in PC-9 and $\mathrm{H} 1650$ cells. Sequence-dependent TGF $\alpha$ expression and release are responsible for the sequence-dependent EGFR pathway modulation.
\end{abstract}

Conclusion: The data suggest that the sequence of paclitaxel followed by gefitinib is an appropriate treatment combination for NSCLC cell lines harboring EGFR mutations. Our results provide molecular evidence to support clinical treatment strategies for patients with lung cancer.

\footnotetext{
* Correspondence: syylwu@live.cn

${ }^{1}$ Guangdong Lung Cancer Institute; Medical Research Center of Guangdong

General Hospital \& Guangdong Academy of Medical Sciences. No.106,

Zhongshan 2nd Rd, Guangzhou, Postal code:510080, People's Republic of

China

Full list of author information is available at the end of the article
} 


\section{Background}

Despite recent advances in early diagnosis and treatment, non-small cell lung cancer (NSCLC) is still a disease with a poor prognosis. Platinum-based doublet chemotherapy is the mainstay of treatment for advanced NSCLC with good performance status [1,2]. Current data suggest that NSCLC chemotherapy has reached a therapeutic plateau [3,4].

Gefitinib and erlotinib are orally active, reversible Her-1/epidermal growth factor receptor tyrosine kinase inhibitors (EGFR-TKIs). In 2004, researchers found that EGFR-activating mutations correlated with clinical responses [5-7]. The Iressa Pan-Asia Study (IPASS) trial indicated that gefitinib was superior to carboplatin plus paclitaxel as an initial treatment for patients with advanced NSCLC harboring an EGFR mutation [8]. The finding was further supported by two randomized studies (the WJTOG3405 and NEJ 002 trials) that consistently reported a high tumor response rate and progression-free survival (PFS) in patients with an EGFR mutation $[9,10]$. The EGFR mutation rate was higher in Asian than in western patients, explaining the higher response rate in East Asian patients [11]. Based on these studies, an EGFR mutation is currently the only established predictive factor for EGFR-TKIs.

An increasingly interesting area of clinical research is the development of rationale combinations of cytotoxic drugs with molecularly targeted therapies to increase the therapeutic potential by blocking cancer cell survival mechanisms. Recently, we have shown that the sequence of paclitaxel followed by gefitinib improves the antiproliferative effect compared with other sequences and produced a synergistic effect. We also found the sequence-dependent modulation of EGFR phosphorylation plays a role in this sequence-dependent antiproliferative effect [12]. However, we did not focus on cell lines with mutant EGFR and the exact mechanism underlying the modulation of EGFR phosphorylation remains to be determined. While other studies indicated that TGF $\alpha$ release is responsible for EGFR activation induced by radiotherapy $[13,14]$, we hypothesized that TGF $\alpha$ might play a role in the sequencedependent antiproliferative effect.

Thus, the present study was performed in NSCLC cell lines harboring EGFR-activating mutations to investigate the synergistic interaction between paclitaxel and gefitinib, and to determine the underlying mechanism(s). We found that sequence-dependent TGF $\alpha$ expression and release were responsible for the sequence-dependent EGFR pathway modulation and sequence-dependent antiproliferative effect.

\section{Materials and methods Drugs and chemicals}

Pure gefitinib, kindly provided by AstraZeneca (London, UK), was dissolved in dimethyl sulfoxide (DMSO) as a $20 \mathrm{mM}$ stock solution. Paclitaxel was purchased from Sigma (St. Louis, MO, USA) and was dissolved in DMSO as a $1 \mathrm{mM}$ stock solution. Both drugs were diluted with culture medium before use.

Primary antibodies: anti-pY1068 EGFR (phosphotyrosine-specific EGFR antibody) and anti- $\beta$-actin were purchased from Cell Signaling Technology (Danvers, MA, USA), anti-EGFR was purchased from Santa Cruz Biotechnology (Santa Cruz, CA, USA), and anti-TGFa antibody[189-2130.1] was purchased from Abcam (Cambridge, MA, USA).

\section{Cell lines}

The human lung adenocarcinoma cell lines PC-9, Hcc827, and H1650 were kindly provided by Dr. Tony Mok (Chinese University of Hong Kong). These cell lines have been extensively characterized. PC-9 is derived from a patient with adenocarcinoma, harboring an EGFR exon 19 in-frame deletion[E746-A750] that is highly sensitive to EGFR-TKIs [15], Hcc827 is derived from lung adenocarcinomas harboring an EGFR exon 19 in-frame deletion that is highly sensitive to EGFR-TKIs [16]. H1650 carries an EGFR exon 19 in-frame deletion mutation and is resistant to EGFR-TKIs. Martin et al. reported the homozygous deletion of PTEN in H1650 cells, which activated EGFR and contributed to erlotinib resistance [17]. PC-9/GR is a gefitinib-acquired resistant cell line that was established by chronic exposure of PC9 cells to medium with increasing concentrations of gefitinib. Briefly, PC-9 cells were exposed to $10 \mathrm{nmol} / \mathrm{L}$ of gefitinib in medium containing $10 \%$ fetal bovine serum, and the concentration was increased in a stepwised manner. Cells that were able to grow in $1 \mu \mathrm{mol} / \mathrm{L}$ gefitinib were obtained 6 month after initial expose. The decreased sensitivity did not recover even the cells were kept in culture for $>4$ month without gefitinib. These cells were grown in RPMI 1640 medium supplemented with $10 \%$ fetal bovine serum (FBS), penicillin $(100 \mathrm{UI} / \mathrm{ml})$, and streptomycin $(100 \mu \mathrm{g} / \mathrm{ml})$ at $37^{\circ} \mathrm{C}$ in a humidified atmosphere with $5 \% \mathrm{CO}_{2}$ and harvested with trypsinEDTA when the cells were in exponential growth.

\section{Sequencing of EGFR gene}

The exons encoding the intracellular domain of EGFR were amplified from genomic DNA and directly sequenced. To further characterize additional mutation, we amplified the EGFR exon 19 to 20 from PC-9 or PC9/GR CDNA, and the PCR products were subcloned 
into plasmid vector, then inserts were isolated and sequenced.

\section{Treatment regimens}

Cell viability was determined using the MTT (3- $(4,5-$ dimethylthiazol-2-yl)-2,5- diphenyltetrazolium bromide) assay, according to the method of Mosmann and Carmichael $[18,19]$. To evaluate the antiproliferative effects of combined treatment, cells were treated with three different sequences: I, pretreated with paclitaxel for $24 \mathrm{~h}$, aspirated and washed once with phosphate-buffered saline (PBS), followed by gefitinib for $48 \mathrm{~h}$; II, pretreated with gefitinib for $48 \mathrm{~h}$, aspirated and washed once with PBS, followed by paclitaxel for $24 \mathrm{~h}$; III, treated concomitantly with paclitaxel plus gefitinib for $48 \mathrm{~h}$, and then incubated in drug-free medium for $24 \mathrm{~h}$. The different drug doses were combined using constant ratios of the $\mathrm{IC}_{50}$ values, calculated from previous cytotoxicity tests. Thus, we used $0.125,0.25,0.5,1,2$, and 4 times the IC50 dose in paclitaxel and gefitinib combination doses to calculate the CI value. The results of sequential treatment with paclitaxel and gefitinib were analyzed according to the method of Chou and Talaly [20]. The resulting combination index $(\mathrm{CI})$ represented a quantitative measure of the degree of interaction between different drugs, with $\mathrm{CI}>1.1, \mathrm{CI}=0.9-1.1$, and $\mathrm{CI}<0.9$ indicating antagonistic, additive, and synergistic effects, respectively. The CI value was calculated using the CompuSyn software (ComboSyn, Inc., Paramus, NJ, USA).

\section{Western blot analysis}

Cells were seeded at $1 \times 10^{5}$ per plate on 10 -cm plates and left to settle overnight. Cells were then treated by adding fresh medium containing drugs for the desired times. Soluble protein was extracted with the addition of RIPA lysis solution. Lysates were cleared by centrifugation (12000 rpm, $4^{\circ} \mathrm{C}, 15 \mathrm{~min}$ ), and soluble protein extracts were stored frozen at $-80^{\circ} \mathrm{C}$. Protein concentrations were quantitated using the bicinchoninic acid assay [21]. Total cell extracts $(30 \mu \mathrm{g}$ of protein/well) were resolved on $8-10 \%$ acrylamide Tris-acetate gels, and then proteins were transferred to a polyvinylidene fluoride (PVDF) membrane, blocked for $1 \mathrm{~h}$ at room temperature in $5 \% \mathrm{w} / \mathrm{v}$ non-fat milk diluted in Trisbuffered saline Tween 20 (TBST), and finally incubated with appropriate primary antibodies under the conditions recommended by the manufacturers. The blots were then washed with TBST for $30 \mathrm{~min}$ and incubated with horseradish peroxidase-conjugated secondary antibody at room temperature for $1 \mathrm{~h}$. Antibody binding was detected using an enhanced chemiluminescence system(Santa Cruz, CA, USA).
To quantify protein levels, films were scanned and analyzed with the Labworks software(World BioHazTec Corp, NM, USA). The relative protein levels were counted using a comparison with the untreated control.

\section{Real-time polymerase chain reaction (PCR)}

To compare the possible influence of TGFa gene expression on the sequence-dependent synergistic effect between paclitaxel and gefitinib, we used PC-9 cells to analyze the sequential modulation of TGFa expression. The primer and probe design, total RNA isolation, cDNA synthesis, and quantification standards for real-time PCR were performed as described previously [22,23]. Total RNA was isolated using the Trizol reagent (Invitrogen) according to the manufacturer's protocol. The integrity of the total RNA was examined by $1 \%$ agarose gel electrophoresis, the quantity was determined based on the absorbance at 260 $\mathrm{nm}\left(\mathrm{A}_{260}\right)$, and the purity was analyzed based on the absorbance ratio at 260 and $280 \mathrm{~nm}$. For pure RNA the ratio of $\mathrm{A} 260 / 280$ is $\sim 2.0\left(\mathrm{~A}_{260 / 280}\right.$; Amersham Biosciences GeneQuant, Pittsburgh, PA, USA). cDNA was synthesized from total RNA $(1 \mu \mathrm{g})$ using AMV reverse transcriptase XL (Takara Bio, Inc., Shiga, Japan). $\beta$ actin served as an internal control. To create real-time PCR standards, TGF $\alpha$ and $\beta$-actin were amplified using reverse transcriptase-PCR and specific primers. The amplicons were cloned into the pMD18-T vector (Takara) and the sequence was confirmed by sequencing. The purified recombinant DNA was quantified and then serially diluted in ultra-pure water to a final concentration ranging from $10^{7}$ to $10^{1}$ copies/ $\mu \mathrm{L}$. For quantification standards, we used $1-\mu \mathrm{L}$ aliquots of 10-fold serial dilutions of plasmid DNA. A new standard curve was run for each real-time PCR, and each test run included a control containing non-target DNA. The amount of TGF $\alpha$ mRNA was normalized to the expression values of the housekeeping gene $\beta$-actin.

\section{TGF $\alpha$ enzyme-linked immunosorbent assay (ELISA)}

Medium was harvested from cells grown on 6-well dishes. Samples were processed using the human TGFa quantikine ELISA kit (R\&D systems, Inc., Minneapolis, $\mathrm{MN}$, USA) according to the manufacturer's instructions.

\section{Statistics}

Results are presented as the mean \pm standard error (SE) of at least three experiments. Statistical comparisons of sequence-dependent effects were conducted by student's $t$ tests. Statistics and graphs were generated using the GraphPad Prism software (ver. 5.00 for windows, GraphPad Software Inc, CA, USA). 


\section{Results}

The potential mechanisms for gefitinib resistance in PC-9/ GR cells

The gefitinib-acquired resistant PC-9/GR cells were obtained 6 months after initial exposure. These cells were 100-fold more resistant than parental cells(Table-1). Additional mutations were not detected by direct sequencing. The PCR product of PC-9 and PC-9/GR were subcloned into a plasmid vector, then the inserts were randomly selected and sequenced. Among the 20 sequences from PC-9/GR, we found 6 sequences were wild-type, 11 had only the 15-bp deletion, and 3 had both the 15-bp deletion and T790M mutation. These T790M mutation seemed to be the cause of gefitinib resistance. Of 10 colones isolated from PC-9, 4 had no mutation, and the others had the 15-bp deletion (Figure 1).

\section{Sequence-dependent antiproliferative effects differed between EGFR-TKI-sensitive and EGFR-TKI-resistant NSCLC cell lines}

To evaluate the antiproliferative effects of paclitaxel and gefitinib treatment, we performed a series of MTT cell growth assays. Treatment with gefitinib alone for $72 \mathrm{~h}$ resulted in a dose-dependent inhibition of cancer cell growth. Table 1 summarizes the $\mathrm{IC}_{50}$ of these two drugs. PC-9 and Hcc827 were highly sensitive to gefitinib, while $\mathrm{H} 1650$ exhibited primary resistance and PC9/GR showed acquired resistance to gefitinib. All of these cell lines demonstrated similar sensitivities to paclitaxel. We evaluated the growth inhibition effect on Hcc827, PC-9, PC-9/GR, and H1650 of three different sequences of combined paclitaxel and gefitinib treatments. Figure 2a shows the schema for in vitro sequential treatment between paclitaxel and gefitinib. As shown in Figure 2b and 2c, the antiproliferative effects between paclitaxel and gefitinib were sequence-dependent. Although the differences were not marked, the sequence of paclitaxel followed by gefitinib was most efficacious against EGFR-mutant NSCLC cells.

The calculation of $C I$ values revealed that the sequence of paclitaxel followed by gefitinib produced synergistic effects. In Hcc827 and PC-9 cell lines, which were highly sensitive to EGFR-TKIs, the sequence of paclitaxel followed by gefitinib resulted in synergistic effects, with mean CI values of 0.63 in Hcc827, 0.54 in PC-9. Concomitant administration of the drugs resulted in both synergistic and additive effects, with mean CI values of 0.88 in Hcc827, 0.91 in PC-9. The gefitinib followed by paclitaxel sequence resulted in an additive and antagonistic interaction with mean CI values of 1.29 in Hcc827, 1.16 in PC-9 (Figure 3a,b). In the PC-9/GR cell line, which exhibited acquired resistance to EGFR-TKIs, the sequence of paclitaxel followed by gefitinib resulted in a synergistic and additive interaction with increasing drug concentrations (mean CI, 0.81). In contrast, the sequence of gefitinib followed by paclitaxel resulted in an antagonistic effect (mean CI, 1.52). Concomitant treatment with the two drugs resulted in additive and antagonistic effects (mean CI, 1.05)(Figure 3c). In the H1650 cell line, a synergistic and additive growth inhibition effect was found with the sequence of paclitaxel followed by gefitinib (mean CI, 0.77). In contrast, the sequence of gefitinib followed by paclitaxel resulted in an antagonistic interaction (mean CI, 1.5). Simultaneous administration of the two drugs resulted in an additive and antagonistic interaction (mean CI, 1.18) (Figure 3d). Each experiment was repeated in triplicate.

\section{Sequence-dependent modulation of the EGFR signaling pathway}

To gain insight into the mechanisms involved regulating the interaction between paclitaxel and gefitinib, we examed the effect of paclitaxel on EGFR phosphorylation. In cell lines of PC-9 and H1650, a dose-dependent increase in pEGFR levels were observed 24 hous after 1 , 2 and 3 fold IC50 dose of paclitaxel exposure(Figure 4). Because EGFR-TKIs specifically target the tyrosine kinase activity of EGFR, we analyzed the sequencedependent modulation of the EGFR signaling pathway using an $\mathrm{IC}_{50}$ dose of paclitaxel plus gefitinib combination. As shown in Figure 5, gefitinib significantly inhibited EGFR phosphorylation $(p<0.01)$. When Hcc827, PC-9, PC-9/GR and H1650 cell lines were exposed to paclitaxel alone, phosphorylated EGFR (pEGFR) levels increased significantly after paclitaxel exposure for $24 \mathrm{~h}$ than that in untreated control (mean difference, $+50 \%$ in $\mathrm{Hcc} 827,+56 \%$ in PC-9, $+39 \%$ in PC-9/GR and $+69 \%$ in $\mathrm{H} 1650$ cells respectively, $p<0.05)$. The increase in pEGFR induced by paclitaxel was blocked by adding gefitinib. In the reverse sequence, gefitinib treatment for 48 h significantly inhibited pEGFR levels, compared with the untreated control level of pEGFR, and subsequent paclitaxel exposure for $24 \mathrm{~h}$ enhanced pEGFR levels. The paclitaxel followed by gefitinib sequence produced significantly greater pEGFR inhibition than did the reverse sequence (mean difference, $-58 \%$ in Hcc 827 , $-38 \%$ in $\mathrm{PC}-9,-35 \%$ in $\mathrm{PC}-9 / \mathrm{GR}$ and $-30 \%$ in $\mathrm{H} 1650$ respectively, $p<0.05$ ).

These data suggest that paclitaxel may also have a self-limiting effect on its toxicity, via activation of the EGFR tyrosine kinase phosphorylation, leading to increased proliferation and survival of paclitaxelmediated cytotoxicity. The increase in pEGFR can be blocked by adding gefitinib, which produces a synergistic effect. In the reverse sequence, however, the sequence of gefitinib followed by paclitaxel interferes with the inhibition of pEGFR by gefitinib. 


\section{A}
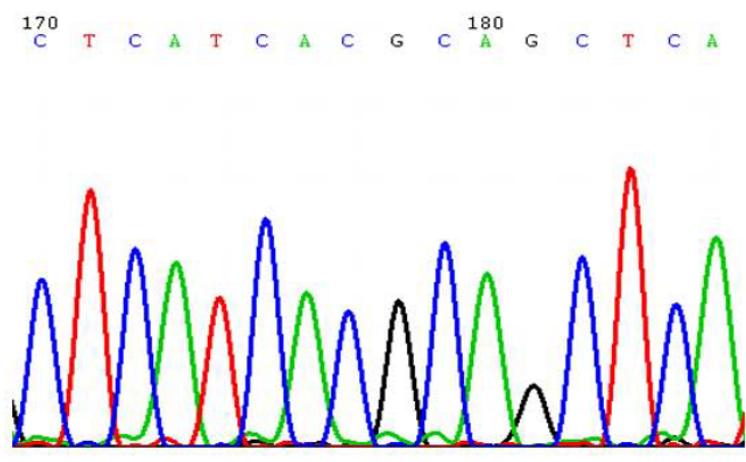

B<smiles>C=[14CH2]</smiles>

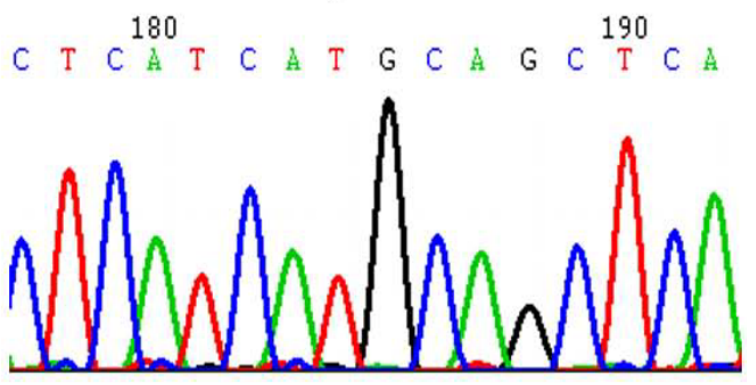

C
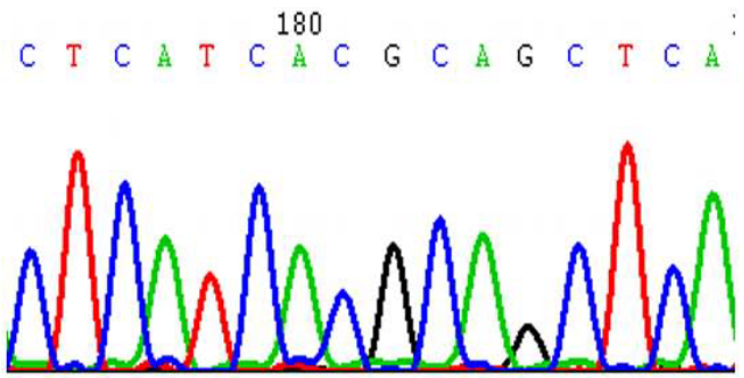

Figure 1 PC-9/GR exon 20 sequence. A. Wild type by direct sequencing. B. 3 of 20 clones had ACG > ATG T790M mutation by clone sequencing. C. 17 of 20 clones were wild type.

\section{Paclitaxel-induced primary activation of EGFR is blocked} by a neutralizing antibody to TGF $\alpha$

Several studies have demonstrated that chemotherapy activates EGFR phosphorylation [24]. Multiple mechanisms allow for EGFR activation and persistent tumor cell proliferation, including activating mutations, receptor amplification, and ligand up-regulation $[25,26]$. Other studies have found that radiation causes release of TGF $\alpha$, which is responsible for activation of the
EGFR signaling pathway [13]. We next examined whether activation of the EGFR signaling pathway induced by paclitaxel is dependent on TGF $\alpha$. Paclitaxel caused EGFR activation in PC-9 and H1650 cells after a 12-h exposure and lasted for $48 \mathrm{~h}$. Addition of a neutralizing antibody to TGF $\alpha$ reduced the activation of EGFR (Figure 6). These data demonstrated that paclitaxelinduced EGFR activation was dependent on the function of TGF $\alpha$. 
Table 1 IC50 values for each drug were calculated by performing dose response experiments with gefitinib and paclitaxel

\begin{tabular}{lllll}
\hline IC50 & Hcc827 & PC-9 & PC-9/GR & H1650 \\
\hline Paclitaxel & $2.27 \pm$ & $2.33 \pm$ & $2.59 \pm$ & $3.29 \pm$ \\
& $0.15 \mathrm{nM}$ & $0.47 \mathrm{nM}$ & $0.62 \mathrm{nM}$ & $0.35 \mathrm{nM}$ \\
\hline Gefitinib & $16 \pm 1.12 \mathrm{nM}$ & $19 \pm 2 \mathrm{nM}$ & $2.1 \pm 0.39 \mu \mathrm{M}$ & $9.37 \pm$ \\
& & & & $0.52 \mu \mathrm{M}$ \\
\hline
\end{tabular}

TGF $\alpha$ is a cognate ligand for EGFR, mediate tyrosine phosphorylation of the receptor. We then determine the growth inhibition effect of an anti-TGF $\alpha$ antibody. PC-9 and $\mathrm{H} 1650$ cells were grow into the medium containing increasing concentration of anti-TGF $\alpha$ antibody for 72 hours. The antibody show a modest growth inhibition effect, inhibited the growth of PC-9 and H1650 by about $30 \%$ at $500 \mathrm{ng} / \mathrm{ml}$ (Figure 7).

\section{Sequence-dependent TGF $\alpha$ expression and release are responsible for the sequence-dependent EGFR pathway modulation}

To further evaluate whether sequential modulation of the EGFR pathway is due to the release of TGF $\alpha$, PC-9, Hcc827 and H1650 cells were treated with sequential paclitaxel and gefitinib as indicated in the treatment schema of Figure 2a. Medium was subjected to ELISA to verify soluble TGF $\alpha$ levels and was normalized to cell numbers. As shown in Figure 8a, paclitaxel exposure for 24 h significantly stimulated TGF $\alpha$ release. Gefitinib significantly inhibited the release of TGF $\alpha(p<0.05)$. The paclitaxel-followed-by-gefitinib sequence resulted in a significant reduction of TGF $\alpha$ levels, compared with the reverse sequence $(p<0.05)$.

To gain further insight into the mechanisms involved in regulating the interaction between paclitaxel and gefitinib, we examined changes in TGF $\alpha$ mRNA expression in treated PC-9, Hcc827 and H1650 cells. Quantitative PCR analysis of TGF $\alpha$ mRNA expression levels showed that in comparison with the respective control, paclitaxel significantly increased $(p<0.01)$, while gefitinib significantly decreased TGF $\alpha$ mRNA expression $(p<$ $0.05)$. The paclitaxel-followed-by-gefitinib sequence significantly decreased TGF $\alpha$ mRNA expression, compared with the reverse sequence (Figure $8 \mathrm{~b} ; p<0.05$ ).

\section{Discussion}

The present study demonstrated that the antiproliferative effect with paclitaxel and gefitinib is sequencedependent in EGFR-mutant NSCLC cells. We found that the sequence of paclitaxel followed by gefitinib

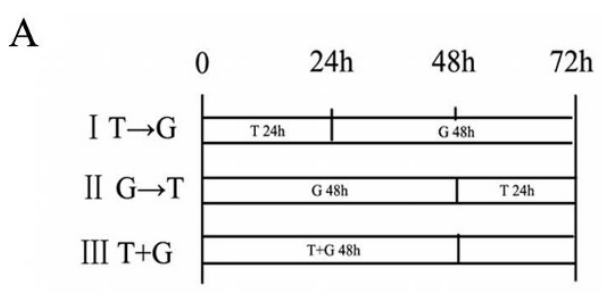

B

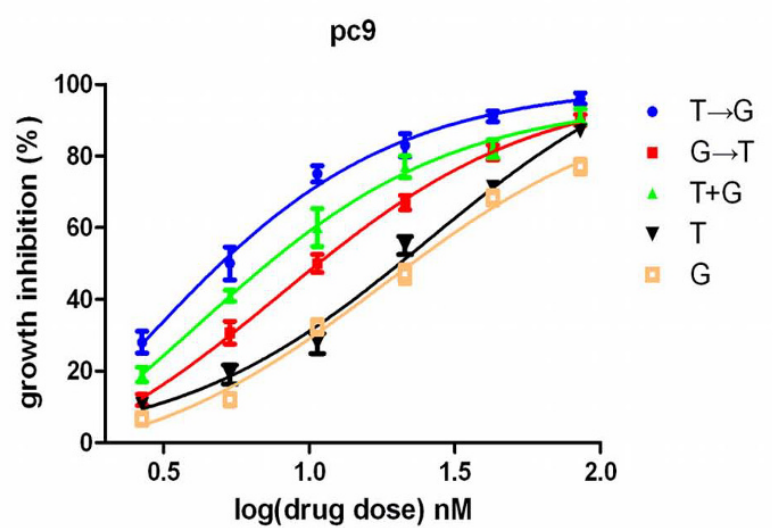

$\mathrm{C}$

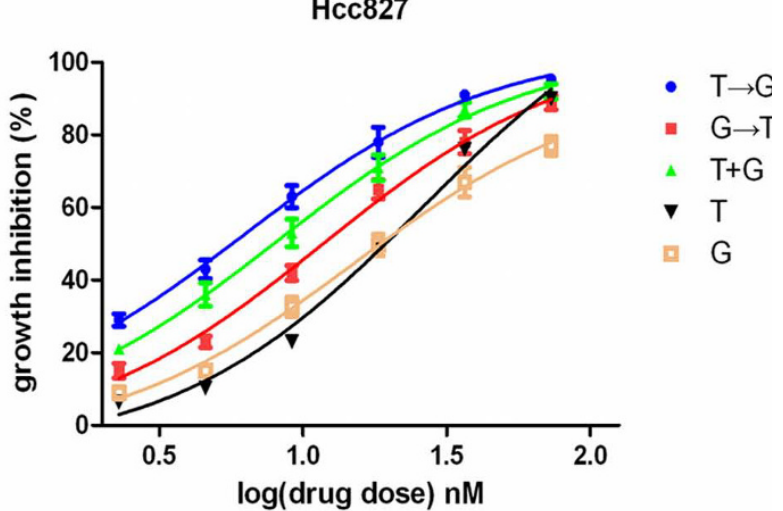

Figure 2 The antiproliferative effect with paclitaxel and gefitinib is sequence-dependent. A. Schema of sequential treatment. B and C. The sequence of paclitaxel followed by gefitinib produced the most potent antiproliferative effect in PC-9 and Hcc827 cells. T $\rightarrow$ G, paclitaxel followed by gefitinib. $G \rightarrow T$, gefitinib followed by paclitaxel. $T+G$, concomitant paclitaxel and gefitinib. T, paclitaxel alone for $72 \mathrm{~h}$. $G$, gefitinib alone for $72 \mathrm{~h}$ 
A

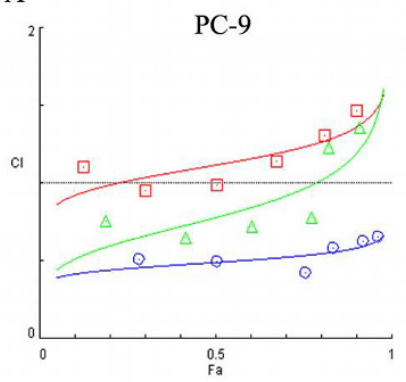

$\mathrm{C}$

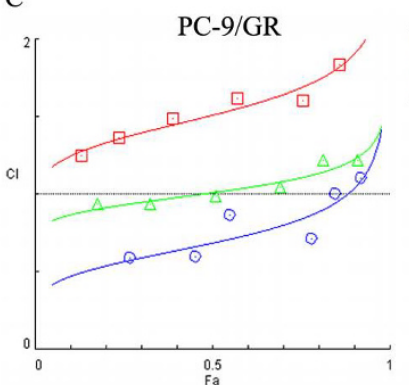

B

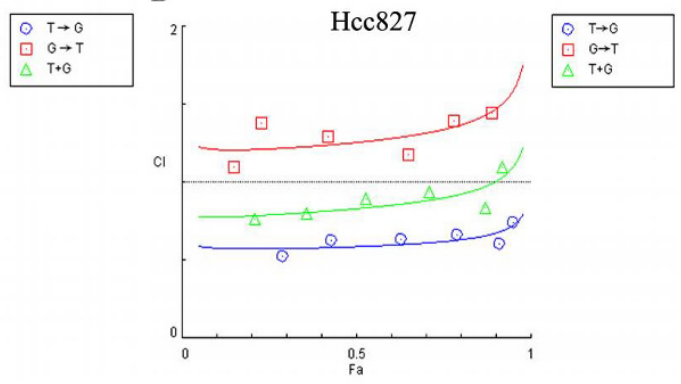

$\mathrm{D}$

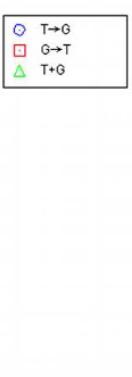

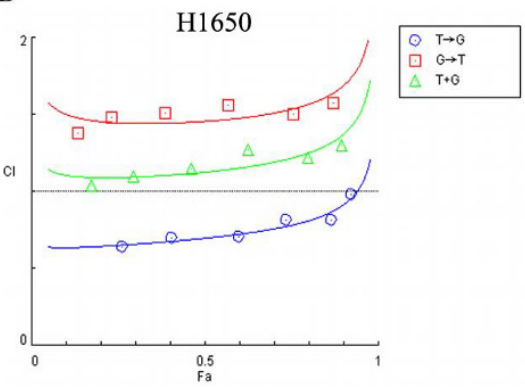

Figure 3 Synergism of sequence-dependent cytotoxicity between paclitaxel and gefitinib. Points, mean values of three different experiments. $\circ T \rightarrow G$, paclitaxel followed by gefitinib. $\square G \rightarrow T$, gefitinib followed by paclitaxel. $\Delta T+G$, concomitant paclitaxel and gefitinib. The sequence $T \rightarrow G$ produced the most potent cytotoxic growth inhibition. The $T \rightarrow G$ sequence resulted in a synergistic effect.

produced the most efficacious antiproliferative effect. Other studies have demonstrated sequence-dependent interaction between EGFR-TKIs and chemotherapy in human cancer cell lines [27]. These studies also revealed that pretreatment with erlotinib caused G1 arrest and effectively abrogated the activity of chemotherapy, resulting in decreased cytotoxicity and decreased apoptosis [28-30]. Solit et al. reported schedule-dependent efficacy in an NSCLC xenograft model with paclitaxel and gefitinib [31]. Our study was novel because we found that sequence-dependent modulation of the EGFR signaling pathway might play a role in the sequence-dependent interaction in NSCLC cells harboring an EGFR mutation. We found that paclitaxelinduced activation of EGFR was dependent on the function of TGF $\alpha$. Additionally, TGF $\alpha$ expression and release were sequence-dependent, which may responsible for the sequence-dependent interaction between paclitaxel and gefitinib.

As EGFR-TKIs gefitinib and erlotinib are active in patients with NSCLC harboring EGFR mutations, combining them in treatment with chemotherapy was deemed promising [8,9]. However, in the INTACT-1, INTACT-2, TALENT, and TRIBUTE clinical trials, the addition of gefitinib or erlotinib to first-line chemotherapy failed to improve survival [32-35]. In a phase II trial of CALGB 30406, the concurrent combination of paclitaxel plus carboplatin with erlotinib showed a similar efficacy compared with erlotinib alone in patients with advanced lung adenocarcinoma [36]. Gandara et al. $[37,38]$ proposed two hypotheses that seem reasonable to explain the negative results. First, patients were not selected based on a predictive response marker, although other studies have reported that activating mutations in the EGFR tyrosine kinase domain were associated with a dramatic response to gefitinib and erlotinib. Second, potentiation of the antagonistic interaction between concurrent EGFR-TKI and chemotherapy may have played a role, because in vitro and in vivo studies of administration of concurrent EGFR-TKI and chemotherapy have suggested antagonism. Davies et al. [39] have proposed the pharmacodynamic separation model: EGFR-TKIs primarily cause cell cycle arrest and accumulation of cells in G1; and thus, when administered concurrently with chemotherapy, can interfere with cell cycle-specific cytotoxicity. Our previous study [12] and other study [30] found that EGFR-TKI induces G1 arrest, which produced a negative interaction when combined concurrently with chemotherapy or followed by chemotherapy.

Chemotherapy has been shown to activate multiple signaling pathways [40] and, recently, to activate the EGFR pathway as well as to enhance ubiquitination and degradation $[41,42]$. The intracellular TK activity of EGFR is increased as a consequence of binding of various cognate ligands, including EGF, TGF $\alpha$, and amphiregulin, leading to homodimerization of two EGFRs or 


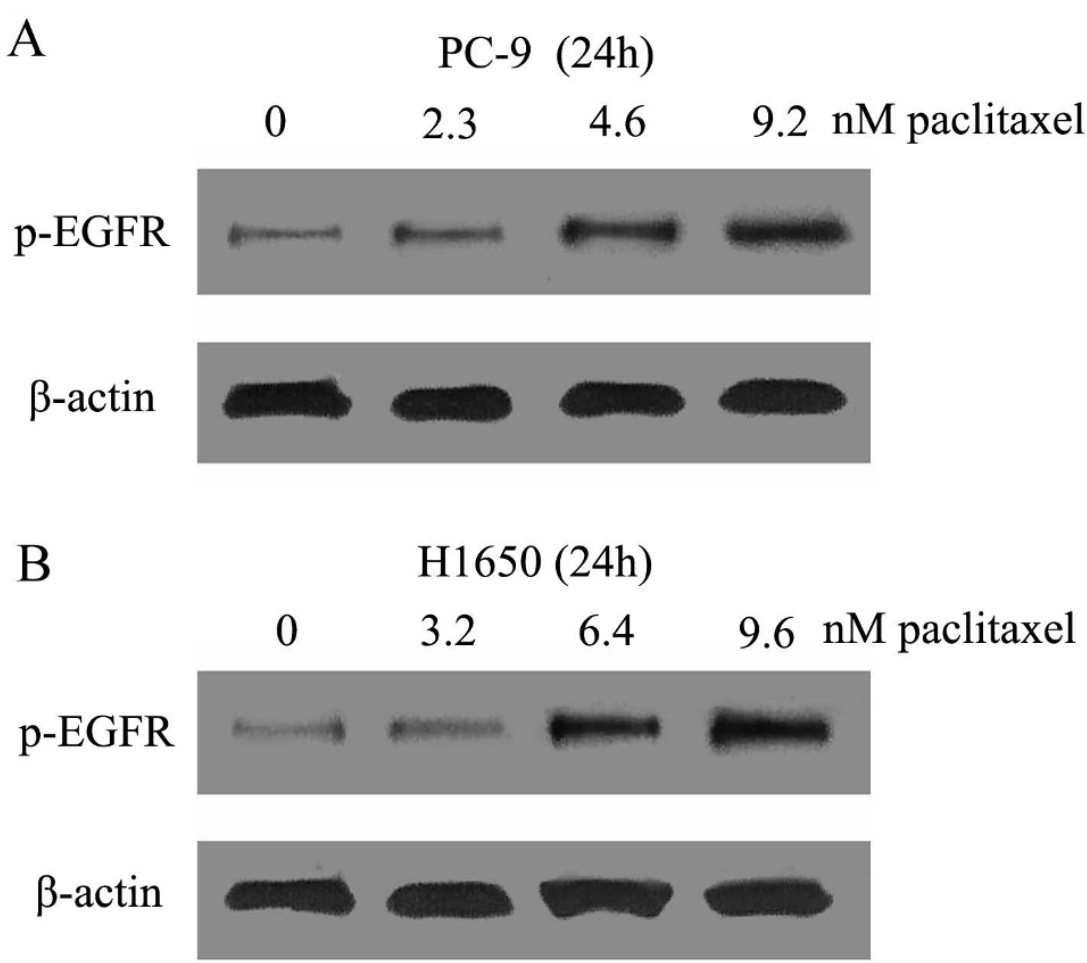

Figure 4 Effect of paclitaxel on EGFR phosphorylation. PC-9 and H1650 cells were exposed to 1, 2 and 3 fold IC50 dose paclitaxel for 24 h. A dose-dependent increase in EGFR phosphorylation levels were observed.

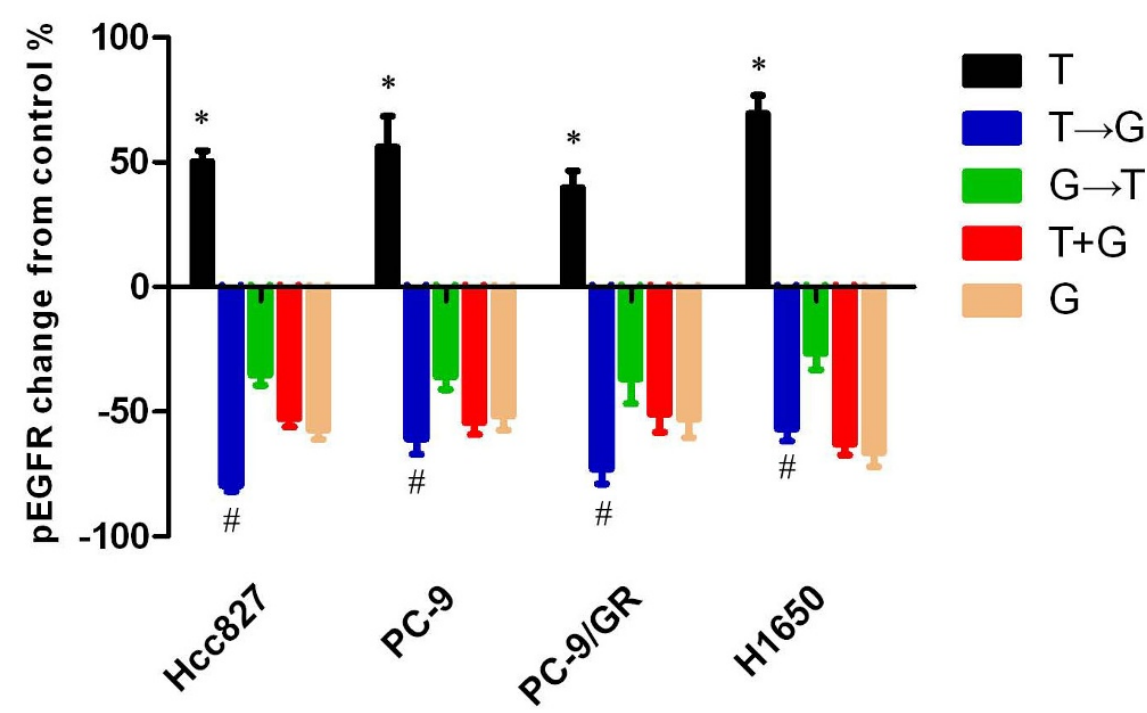

Figure 5 Sequential modulation of EGFR phosphorylation. Cells were exposed to the IC50 dose of gefitinib and paclitaxel using different sequences. *Paclitaxel significantly activated the EGFR pathway compared with control after paclitaxel exposure for $24 \mathrm{~h}(\mathrm{p}<0.05)$. \# $\mathrm{p}<0.05$. The phosphorylated EGFR (p-EGFR) level after treatment with paclitaxel followed by gefitinib was lower than that for gefitinib followed by paclitaxel. 
A

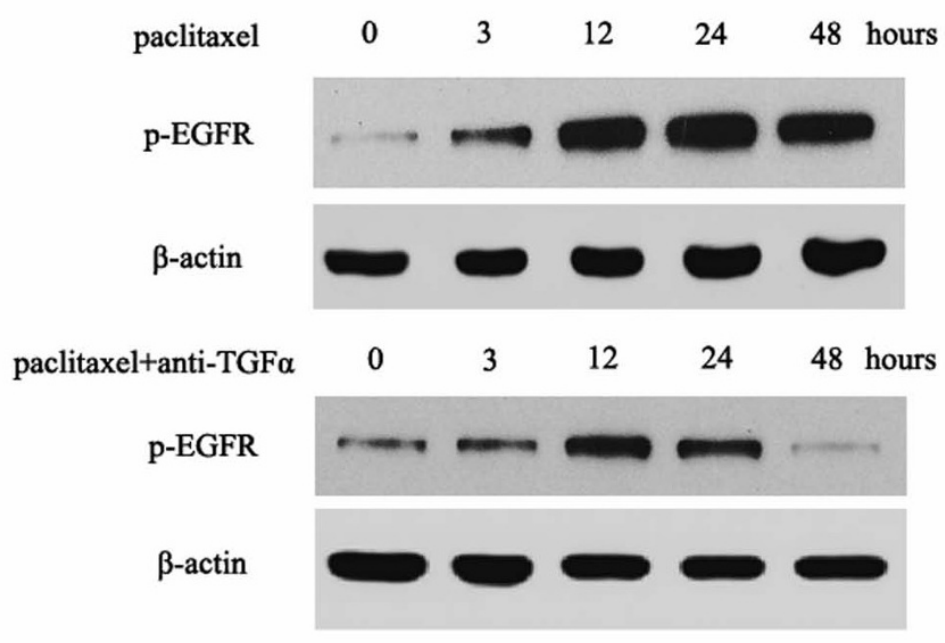

B

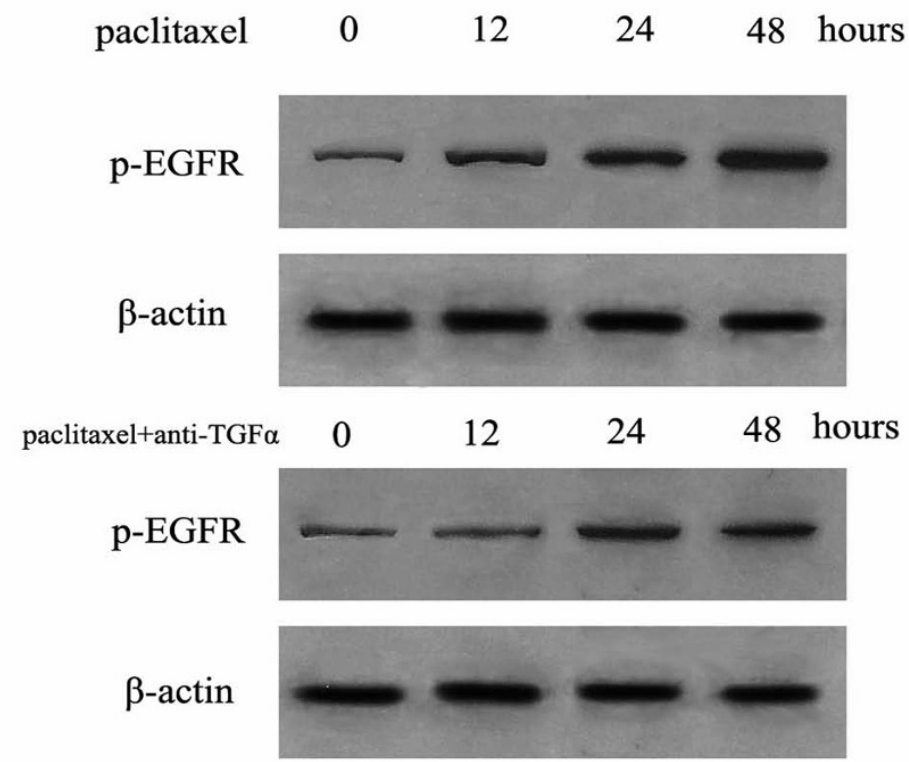

Figure 6 Paclitaxel-induced activation of EGFR is blocked by adding neutralizing TGF $\alpha$ antibody. The dose of paclitaxel is 2-fold IC50. The dose of TGF $\alpha$ antibody is $0.15 \mu \mathrm{g} / \mathrm{mL}$ A.PC-9 B. H1650.

heterodimerization of EGFR with other family members [43]. Improper activation of EGFR TK results in increased malignant cell survival, proliferation, invasion, and metastasis [44,45]. Several chemotherapy drugs were found to activate the EGFR signaling pathway [41]. Radiation has also been demonstrated to activate the EGFR signaling pathway by causing the release of $\mathrm{TGF} \alpha$, which is responsible for secondary activation of EGFR, mitogen-activated protein kinase (MAPK), and Janus kinase (JNK) pathways [13]. In the present study, neutralizing TGF $\alpha$ abolished the paclitaxel induced- activation of EGFR, and paclitaxel may stimulate release of TGF $\alpha$ to activate the EGFR pathway.

Autocrine loops are established when soluble factors secreted by cells bind to and stimulate receptors on their own surfaces [46]. TGF $\alpha$ is a cognate ligand for EGFR and can establish an autocrine loop that leads to receptor hyperactivity [47]. Ciardiello, et al. found that a TGF $\alpha$-EGFR autocrine growth pathway is active in cancer cell lines, and gefitinib produced a dose-dependent inhibition of the secretion of TGF $\alpha$ [48]. Our data suggest that paclitaxel may exert a self-limiting effect on its 


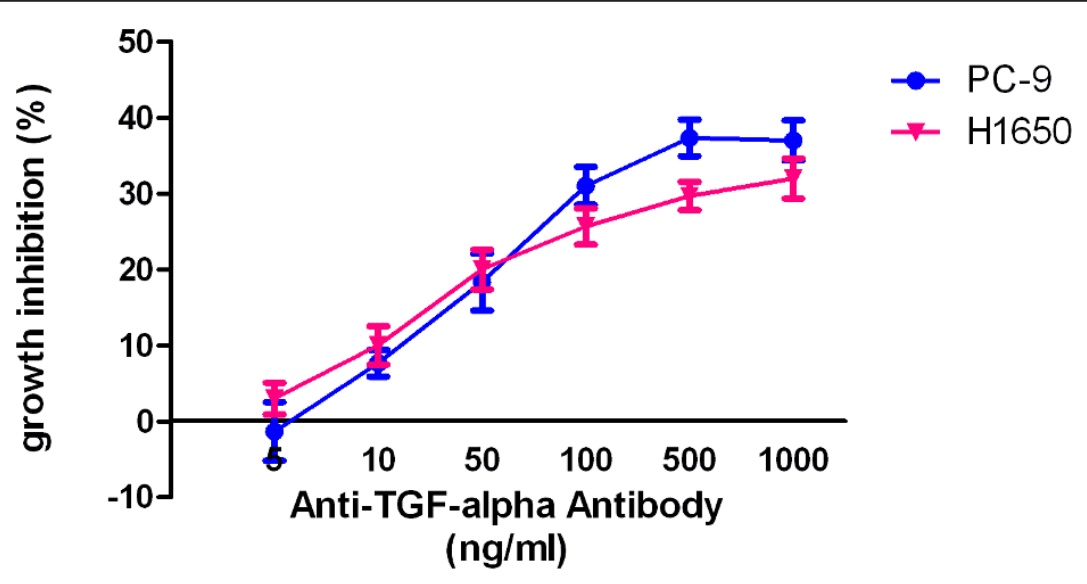

Figure 7 Growth inhibition of PC-9 and H1650 by an anti-TGF $\alpha$.antibody. PC-9 and H1650 cells were grow into a 96 well plate. The following day, the cells were incubated with indicated concentration of anti-TGF $\alpha$ antibody for $72 \mathrm{~h}$. The inhibition ratio were determined by MTT assay.

\section{A}

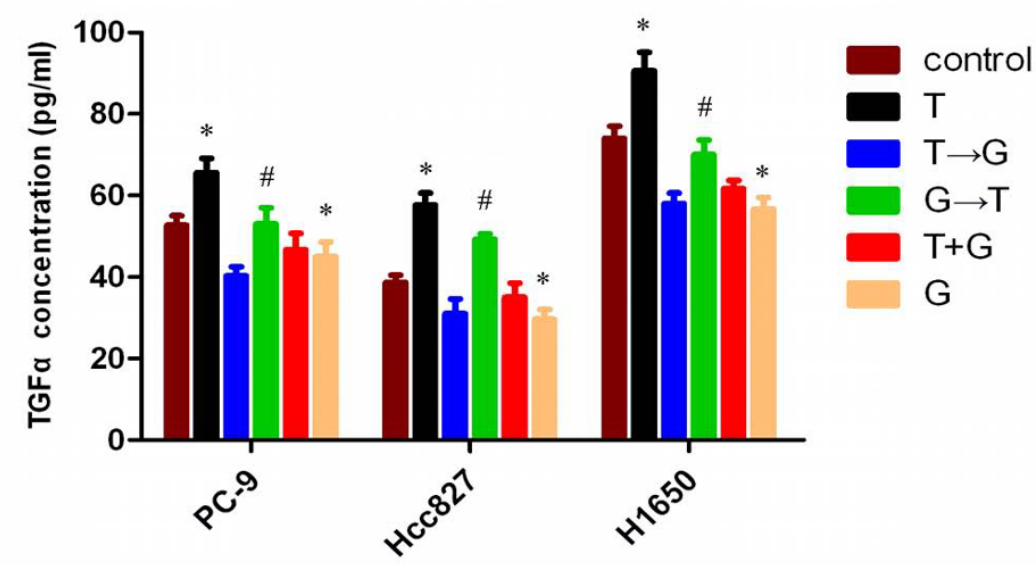

B

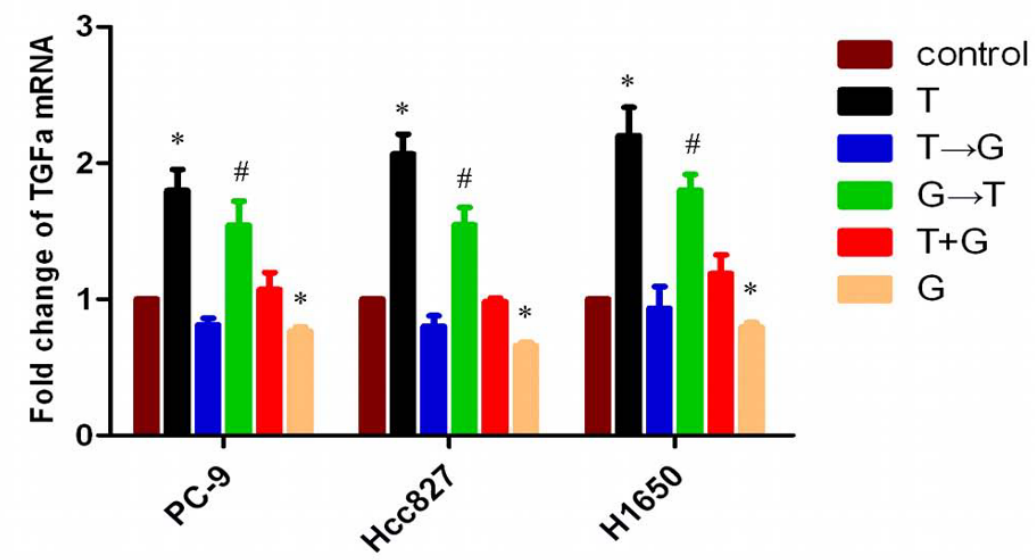

Figure 8 Sequential modulation of TGF $\alpha$ release and expression. Cells were exposed to IC50 dose of paclitaxel and gefitinib with different sequence. A, standard enzyme-linked immunosorbent assay analysis of soluble TGF $\alpha$ levels in PC-9, Hcc827 and H1650 cells. ${ }^{*} p<0.05$,

significantly different from control. \#P $<0.05, T \rightarrow G$ VS G $\rightarrow$ T. B, reverse transcription-polymerase chain reaction analysis of TGF $\alpha$ expression. ${ }^{*} p<$ 0.05 , significantly different from control. \#P $<0.05, T \rightarrow G$ vs. $G \rightarrow T$. 
ability to kill and reduce the proliferation of autocrineregulated tumor cells, potentially by increasing both the rates of transcription and activation of TGF $\alpha$. Increased expression and release of TGF $\alpha$ leads to both increased EGFR and activation of the downstream signaling pathway, which, in turn, leads to both increased proliferation of tumor cells as well as other enhanced cytoprotective responses. Increased TGF $\alpha$ expression and release can be blocked by subsequent administration of gefitinib, which can block TGF $\alpha$-triggered EGFR signaling pathway activation and produce a synergistic effect. In contrast, initial exposure to gefitinib decreases TGFa expression and release, and subsequent paclitaxel treatment enhances TGF $\alpha$ expression and release, producing an antagonistic effect.

Cytotoxic chemotherapy treatment for patients with advanced NSCLC has reached a plateau, but further improvements are expected with the integration of targeted therapies $[49,50]$. EGFR-TKIs treatment concurrent with chemotherapy failed to improve survival. Alternative schedules of TKI administration in combination with chemotherapy, such as sequential and pulse administration, are under investigation. In the Fast-Act trial, a randomized phase II trial of sequential erlotinib and chemotherapy as first-line treatment of patients with advanced NSCLC, gemcitabine plus cisplatin or carboplatin (GC) were sequentially followed by erlotinib (GC-E) versus GC followed by a placebo (GC-P). The results revealed that GC-E significantly improved PFS compared with GC-P [51]. Based on these results, FastAct II, a randomized phase III trial of sequential erlotinib and chemotherapy, is underway [52].

In the final analysis of the pivotal IPASS trial, although there is significant improvement in PFS and $R R$ for patients receiving gefitinib, overall survival was similar for gefitinib and carboplatin/paclitaxel, reported Chin-Hsin Yang [53]. The effect of the initial randomized treatment therapy on overall survival is likely to have been confounded by subsequent study, particulary, the switching of patients to the alternative study treatment. This suggests the sequence of therapy may not make a significant impact in patients with mutant EGFR, as long as such patients are exposed to an EGFR TKI in general, and whether it is given first-line or later translates into the same overall survival benefit.

The limitation of this study is that because the short exposure time, the interaction of sequential treatment in vitro may not correlate the interaction between first-line and second-line treatment in clinic. The drug interaction patterns observed in vitro may not be similar to those observed clinically. Because the culture condition can perturb cell function and potentiate drug sensitivity, obtaining good correlations can be problematic. Pharmacokinetics, pharmacodynamics, rescue effects and toxicity to normal cells/tissues that affect drug action in clinical setting are not considered by in vitro assays. Because each patient has a unique pharmacogenetic makeup, correlating in vitro and clinical results is often not a straightforward process. However, our study provided a rational for the ongoing clinical investigation of sequential treatment of NSCLC.

\section{Conclusions}

In summary, our studies have demonstrated that sequential administrations of paclitaxel followed by gefitinib result in the most effective cytotoxic effects in NSCLC cell lines harboring EGFR mutations. The sequence-dependent modulation of TGF $\alpha$ expression and release might be responsible for the synergistic interaction between paclitaxel and gefitinib. Although the extrapolation of in vitro data to the clinical setting should be considered with caution, these results may have implications for the rational development of chemotherapeutic regimens for the treatment of NSCLC.

\section{Acknowledgements}

This work was supported by the grants from the National Natural Science Foundation of China (No. 30772531), and Zhuhai Science \& Technology Bureau (No.20081040)

\section{Author details}

'Guangdong Lung Cancer Institute; Medical Research Center of Guangdong General Hospital \& Guangdong Academy of Medical Sciences. No.106, Zhongshan 2nd Rd, Guangzhou, Postal code:510080, People's Republic of China. ${ }^{2}$ Thoracic oncology, the fifth affiliated hospital of Sun Yat-Sen university. No. 52, Meihua Dong Rd, Zhuhai, Postal code:519000, People's Republic of China.

\section{Authors' contributions}

HC designed thses experiments, performed part of these experiments and drafted this manuscript. YW designed these experiments, analyzed the results, guided these experiments and revised this manuscript. SA and ZC carried out RT-PCR. DS and YZ carried out the western blot, XZ analyzed the experiment results. JS carried out part of the MTT assays. All authors have read and approved the final manuscript.

\section{Competing interests}

Yi-long Wu has received speaking honoraria from AstraZeneca, Eli lilly, F. Hoffmann-La Roche and Pfizer. No other potential conflict of interest relevant to this article was reported.

Received: 14 October 2010 Accepted: 21 January 2011 Published: 21 January 2011

\section{References}

1. Socinski MA, Crowell R, Hensing TE, Langer CJ, Lilenbaum R, Sandler AB, Morris D: Treatment of non-small cell lung cancer, stage IV: ACCP evidence-based clinical practice guidelines. Chest , 2 2007, 132(3 Suppl):277S-289S,

2. Felip E, Stahel RA, Pavlidis N: ESMO Minimum Clinical Recommendations for diagnosis, treatment and follow-up of non-small-cell lung cancer (NSCLC). Ann Oncol 2005, 16(Suppl 1):i28-29.

3. Schiller JH, Harrington D, Belani CP, Langer C, Sandler A, Krook J, Zhu J, Johnson DH: Comparison of four chemotherapy regimens for advanced non-small-cell lung cancer. N Engl J Med 2002, 346(2):92-98.

4. Smit EF, van Meerbeeck JP, Lianes P, Debruyne C, Legrand C, Schramel F, Smit H, Gaafar R, Biesma B, Manegold C, et al: Three-arm randomized 
study of two cisplatin-based regimens and paclitaxel plus gemcitabine in advanced non-small-cell lung cancer: a phase III trial of the European Organization for Research and Treatment of Cancer Lung Cancer Group-EORTC 08975. J Clin Oncol 2003, 21(21):3909-3917.

5. Lynch TJ, Bell DW, Sordella R, Gurubhagavatula S, Okimoto RA, Brannigan BW, Harris PL, Haserlat SM, Supko JG, Haluska FG, et al: Activating mutations in the epidermal growth factor receptor underlying responsiveness of non-small-cell lung cancer to gefitinib. $N$ Engl J Med 2004, 350(21):2129-2139.

6. Paez JG, Janne PA, Lee JC, Tracy S, Greulich H, Gabriel S, Herman P, Kaye FJ, Lindeman N, Boggon TJ, et al: EGFR mutations in lung cancer: correlation with clinical response to gefitinib therapy. Science 2004, 304(5676):1497-1500.

7. Pao W, Miller V, Zakowski M, Doherty J, Politi K, Sarkaria I, Singh B, Heelan R, Rusch $V$, Fulton $L$, et al: EGF receptor gene mutations are common in lung cancers from "never smokers" and are associated with sensitivity of tumors to gefitinib and erlotinib. Proc Natl Acad Sci USA 2004, 101(36):13306-13311

8. Mok TS, Wu YL, Thongprasert S, Yang CH, Chu DT, Saijo N, Sunpaweravong P, Han B, Margono B, Ichinose Y, et al: Gefitinib or carboplatin-paclitaxel in pulmonary adenocarcinoma. N Engl J Med 2009, 361(10):947-957.

9. Mitsudomi T, Morita S, Yatabe Y, Negoro S, Okamoto I, Tsurutani J, Seto T, Satouchi M, Tada H, Hirashima T, et al: Gefitinib versus cisplatin plus docetaxel in patients with non-small-cell lung cancer harbouring mutations of the epidermal growth factor receptor (WJTOG3405): an open label, randomised phase 3 trial. Lancet Oncol 11(2):121-128.

10. Maemondo M, Inoue A, Kobayashi K, Sugawara S, Oizumi S, Isobe H, Gemma A, Harada M, Yoshizawa H, Kinoshita I, et al: Gefitinib or chemotherapy for non-small-cell lung cancer with mutated EGFR. N Engl $J$ Med 362(25):2380-2388.

11. Wu YL, Zhong WZ, Li LY, Zhang XT, Zhang L, Zhou CC, Liu W, Jiang B, $\mathrm{Mu} X \mathrm{~L}$, Lin $J Y$, et al: Epidermal growth factor receptor mutations and their correlation with gefitinib therapy in patients with non-small cell lung cancer: a meta-analysis based on updated individual patient data from six medical centers in mainland China. J Thorac Oncol 2007, 2(5):430-439.

12. Cheng $H$, An SJ, Zhang XC, Dong S, Zhang YF, Chen ZH, Chen HJ, Guo AL, Lin QX, Wu YL: In vitro sequence-dependent synergism between paclitaxel and gefitinib in human lung cancer cell lines. Cancer Chemother Pharmacol

13. Dent P, Reardon DB, Park JS, Bowers G, Logsdon C, Valerie K, SchmidtUllrich R: Radiation-induced release of transforming growth factor alpha activates the epidermal growth factor receptor and mitogen-activated protein kinase pathway in carcinoma cells, leading to increased proliferation and protection from radiation-induced cell death. Mol Biol Cell 1999, 10(8):2493-2506.

14. Schmidt-Ullrich RK, Valerie K, Chan W, Wazer DE, Lin PS: Expression of oestrogen receptor and transforming growth factor-alpha in MCF-7 cells after exposure to fractionated irradiation. Int I Radiat Biol 1992, 61(3):405-415.

15. Koizumi F, Shimoyama T, Taguchi F, Saijo N, Nishio K: Establishment of a human non-small cell lung cancer cell line resistant to gefitinib. Int J Cancer 2005, 116(1):36-44.

16. Amann J, Kalyankrishna S, Massion PP, Ohm JE, Girard L, Shigematsu H, Peyton M, Juroske D, Huang Y, Stuart Salmon J, et al: Aberrant epidermal growth factor receptor signaling and enhanced sensitivity to EGFR inhibitors in lung cancer. Cancer Res 2005, 65(1):226-235.

17. Sos ML, Koker M, Weir BA, Heynck S, Rabinovsky R, Zander T, Seeger JM, Weiss J, Fischer F, Frommolt P, et al: PTEN loss contributes to erlotinib resistance in EGFR-mutant lung cancer by activation of Akt and EGFR. Cancer Res 2009, 69(8):3256-3261.

18. Mosmann T: Rapid colorimetric assay for cellular growth and survival: application to proliferation and cytotoxicity assays. J Immunol Methods 1983, 65(1-2):55-63.

19. Carmichael J, DeGraff WG, Gazdar AF, Minna JD, Mitchell JB: Evaluation of a tetrazolium-based semiautomated colorimetric assay: assessment of chemosensitivity testing. Cancer Res 1987, 47(4):936-942.

20. Chou TC: Theoretical basis, experimental design, and computerized simulation of synergism and antagonism in drug combination studies. Pharmacol Rev 2006, 58(3):621-681.
21. Smith PK, Krohn Rl, Hermanson GT, Mallia AK, Gartner FH, Provenzano MD, Fujimoto EK, Goeke NM, Olson BJ, Klenk DC: Measurement of protein using bicinchoninic acid. Anal Biochem 1985, 150(1):76-85.

22. An SJ, Nie Q, Chen ZH, Lin QX, Wang Z, Xie Z, Chen SL, Huang Y, Zhang AY, Yan JF, et al: KDR expression is associated with the stage and cigarette smoking of the patients with lung cancer. J Cancer Res Clin Oncol 2007, 133(9):635-642.

23. Dong $S$, Guo AL, Chen ZH, Wang Z, Zhang XC, Huang Y, Xie Z, Yan HH, Cheng $H$, WU YL: RRM1 single nucleotide polymorphism -37C->A correlates with progression-free survival in NSCLC patients after gemcitabine-based chemotherapy. J Hematol Oncol 3:10.

24. Giovannetti E, Lemos C, Tekle C, Smid K, Nannizzi S, Rodriguez JA, Ricciardi S, Danesi R, Giaccone G, Peters GJ: Molecular mechanisms underlying the synergistic interaction of erlotinib, an epidermal growth factor receptor tyrosine kinase inhibitor, with the multitargeted antifolate pemetrexed in non-small-cell lung cancer cells. Mol Pharmacol 2008, 73(4):1290-1300.

25. Franovic A, Gunaratnam L, Smith K, Robert I, Patten D, Lee S: Translational up-regulation of the EGFR by tumor hypoxia provides a nonmutational explanation for its overexpression in human cancer. Proc Natl Acad Sci USA 2007, 104(32):13092-13097.

26. Normanno N, De Luca A, Bianco C, Strizzi L, Mancino M, Maiello MR, Carotenuto A, De Feo G, Caponigro F, Salomon DS: Epidermal growth factor receptor (EGFR) signaling in cancer. Gene 2006, 366(1):2-16.

27. Xu JM, Azzariti A, Colucci G, Paradiso A: The effect of gefitinib (Iressa, ZD1839) in combination with oxaliplatin is schedule-dependent in colon cancer cell lines. Cancer Chemother Pharmacol 2003, 52(6):442-448.

28. Li T, Ling YH, Goldman ID, Perez-Soler R: Schedule-dependent cytotoxic synergism of pemetrexed and erlotinib in human non-small cell lung cancer cells. Clin Cancer Res 2007, 13(11):3413-3422.

29. Gumerlock PH, Pryde BJ, Kimura T: Enhanced cytotoxicity of docetaxel OSI-774 combination in non-small cell lung carcinoma (NSCLC). Proc Am Soc Clin Oncol 2003, 22, abstr 2661.

30. Mahaffey CM, Davies AM, Lara PN Jr, Pryde B, Holland W, Mack PC, Gumerlock PH, Gandara DR: Schedule-dependent apoptosis in K-ras mutant non-small-cell lung cancer cell lines treated with docetaxel and erlotinib: rationale for pharmacodynamic separation. Clin Lung Cancer 2007, 8(9):548-553.

31. Solit DB, She Y, Lobo J, Kris MG, Scher HI, Rosen N, Sirotnak FM: Pulsatile administration of the epidermal growth factor receptor inhibitor gefitinib is significantly more effective than continuous dosing for sensitizing tumors to paclitaxel. Clin Cancer Res 2005, 11(5):1983-1989.

32. Giaccone G, Herbst RS, Manegold C, Scagliotti G, Rosell R, Miller V, Natale RB, Schiller JH, Von Pawel J, Pluzanska A, et al: Gefitinib in combination with gemcitabine and cisplatin in advanced non-small-cell lung cancer: a phase III trial-INTACT 1. J Clin Oncol 2004, 22(5):777-784.

33. Herbst RS, Giaccone G, Schiller JH, Natale RB, Miller V, Manegold C, Scagliotti G, Rosell R, Oliff I, Reeves JA, et al: Gefitinib in combination with paclitaxel and carboplatin in advanced non-small-cell lung cancer: a phase III trial-INTACT 2. J Clin Oncol 2004, 22(5):785-794.

34. Herbst RS, Prager D, Hermann R, Fehrenbacher L, Johnson BE, Sandler A, Kris MG, Tran HT, Klein P, Li X, et al: TRIBUTE: a phase III trial of erlotinib hydrochloride (OSI-774) combined with carboplatin and paclitaxel chemotherapy in advanced non-small-cell lung cancer. J Clin Oncol 2005, 23(25):5892-5899.

35. Gatzemeier U, Pluzanska A, Szczesna A, Kaukel E, Roubec J, De Rosa F, Milanowski J, Karnicka-Mlodkowski H, Pesek M, Serwatowski P, et al: Phase III study of erlotinib in combination with cisplatin and gemcitabine in advanced non-small-cell lung cancer: the Tarceva Lung Cancer Investigation Trial. J Clin Oncol 2007, 25(12):1545-1552.

36. Janne PA, Wang XF, Socinski MA: Randomized phase II trial of erlotinib (E) alone or in combination with carboplatin/paclitaxel (CP) in never or light former smokers with advanced lung adenocarcinoma: CALGB 30406. J Clin Oncol 2010, 28(15s), suppl;abstr 7503.

37. Gandara D, Narayan S, Lara PN Jr, Goldberg Z, Davies A, Lau DH, Mack P, Gumerlock P, Vijayakumar S: Integration of novel therapeutics into combined modality therapy of locally advanced non-small cell lung cancer. Clin Cancer Res 2005, 11 (13 Pt 2):5057s-5062s.

38. Gandara DR, Gumerlock PH: Epidermal growth factor receptor tyrosine kinase inhibitors plus chemotherapy: case closed or is the jury still out? J Clin Oncol 2005, 23(25):5856-5858. 
39. Davies AM, Ho C, Lara PN Jr, Mack P, Gumerlock PH, Gandara DR: Pharmacodynamic separation of epidermal growth factor receptor tyrosine kinase inhibitors and chemotherapy in non-small-cell lung cancer. Clin Lung Cancer 2006, 7(6):385-388.

40. Torres K, Horwitz SB: Mechanisms of Taxol-induced cell death are concentration dependent. Cancer Res 1998, 58(16):3620-3626.

41. Chun PY, Feng FY, Scheurer AM, Davis MA, Lawrence TS, Nyati MK: Synergistic effects of gemcitabine and gefitinib in the treatment of head and neck carcinoma. Cancer Res 2006, 66(2):981-988.

42. Ahsan A, Hiniker SM, Ramanand SG, Nyati S, Hegde A, Helman A, Menawat R, Bhojani MS, Lawrence TS, Nyati MK: Role of epidermal growth factor receptor degradation in cisplatin-induced cytotoxicity in head and neck cancer. Cancer Res 70(7):2862-2869.

43. Bazley LA, Gullick WJ: The epidermal growth factor receptor family. Endocr Relat Cancer 2005, 12(Suppl 1):S17-27.

44. Citri A, Yarden Y: EGF-ERBB signalling: towards the systems level. Nature reviews 2006, 7(7):505-516.

45. Ciardiello F, Tortora G: EGFR antagonists in cancer treatment. $N$ Eng/ J Med 2008, 358(11):1160-1174.

46. Sporn MB, Roberts AB: Autocrine secretion-10 years later. Ann Intern Med 1992, 117(5):408-414.

47. Putnam EA, Yen N, Gallick GE, Steck PA, Fang K, Akpakip B, Gazdar AF, Roth JA: Autocrine growth stimulation by transforming growth factoralpha in human non-small cell lung cancer. Surg Oncol 1992, 1(1):49-60.

48. Ciardiello F, Caputo R, Bianco R, Damiano V, Fontanini G, Cuccato S, De Placido S, Bianco AR, Tortora G: Inhibition of growth factor production and angiogenesis in human cancer cells by ZD1839 (Iressa), a selective epidermal growth factor receptor tyrosine kinase inhibitor. Clin Cancer Res 2001, 7(5):1459-1465.

49. Katzel JA, Fanucchi MP, Li Z: Recent advances of novel targeted therapy in non-small cell lung cancer. J Hematol Oncol 2009, 2:2.

50. Mirshahidi HR, Hsueh CT: Updates in non-small cell lung cancer-insights from the 2009 45th annual meeting of the American Society of Clinical Oncology. J Hematol Oncol 3:18.

51. Mok TS, Wu YL, Yu CJ, Zhou C, Chen YM, Zhang L, Ignacio J, Liao M, Srimuninnimit V, Boyer MJ, et al: Randomized, placebo-controlled, phase II study of sequential erlotinib and chemotherapy as first-line treatment for advanced non-small-cell lung cancer. J Clin Oncol 2009, 27(30):5080-5087.

52. Roche HL: A Study of Tarceva (Erlotinib) or Placebo in Combination With Platinum-Based Therapy as First Line Treatment in Patients With Advanced or Recurrent Non-Small Cell Lung Cancer. 2009, ClinicalTrials. gov Identifier NCT00883779.

53. Yang CH, Fukuoka M, Mok TSea: Final overall survival results from a phase III randomized, open-label, first-line study of gefitinib V carboplatin/ paclitaxel in clinically selected patients with advanced non-small cell lung cancer in Asia. 35th ESMO Congress 2010, Abstract LBA2. Presented October 11.

doi:10.1186/1756-8722-4-5

Cite this article as: Cheng et al:: Molecular mechanism of the scheduledependent synergistic interaction in EGFR-mutant non-small cell lung cancer cell lines treated with paclitaxel and gefitinib. Journal of Hematology \& Oncology 2011 4:5.

\section{Submit your next manuscript to BioMed Central and take full advantage of:}

- Convenient online submission

- Thorough peer review

- No space constraints or color figure charges

- Immediate publication on acceptance

- Inclusion in PubMed, CAS, Scopus and Google Scholar

- Research which is freely available for redistribution

Submit your manuscript at www.biomedcentral.com/submit
C Biomed Central 